\title{
Role of prostaglandins in hypoxia-stimulated erythropoietin production
}

\author{
ARMIN KURTZ, WOLFGANG JELKMANN, JOSEF PFEILSCHIFTER, \\ AND CHRISTIAN BAUER \\ Institut für Physiologie, Universität Regensburg, Regensburg; Physiologisches Institut, \\ Medizinische Hochschule Lübeck, Lübeck, Federal Republic of Germany; \\ and Physiologisches Institut, Universität Zürich, Zürich, Switzerland
}

Kurtz, Armin, Wolfgang Jelkmann, Josef PfeilschifTER, AND CHRISTIAN BAUER. Role of prostaglandins in hypoxiastimulated erythropoietin production. Am. J. Physiol. 249 (Cell Physiol. 18): C3-C8, 1985.-The role of prostaglandins in the mediation of hypoxia-stimulated erythropoietin (Ep) production by cultured rat renal mesangial cells was examined. It was found that an increase in prostaglandin $\mathrm{E}_{2}\left(\mathrm{PGE}_{2}\right)$ production accompanied the rise in Ep due to hypoxia $\left(2 \% \mathrm{O}_{2}\right)$. The hypoxia-stimulated increase in Ep production was abolished in the presence of the cyclooxygenase inhibitor indomethacin $\left(10^{-5} \mathrm{M}\right)$. When $\mathrm{P}\left(\mathrm{KF}_{2}\left(10^{-6} \mathrm{M}\right)\right.$ was added simultaneously with indomethacin, however, no diminution in hypoxia-stimulated Ep production was observed. Addition of arachidonic acid (AA, $\left.10^{-5} \mathrm{M}\right), \mathrm{PGE}_{2}\left(10^{-6} \mathrm{M}\right)$, or $\mathrm{PGI}_{2}\left(10^{-4} \mathrm{M}\right)$ enhanced $\mathrm{Ep}$ production under normoxic conditions $\left(20 \% \mathrm{O}_{2}\right)$, while $\mathrm{PGF}_{2 \alpha}$ $\left(10^{-6} \mathrm{M}\right)$ had no effect on Ep production. $\mathrm{AA}, \mathrm{PGE}_{2}$, and $\mathrm{PGI}_{2}$ were found to stimulate adenosine $3^{\prime}, 5^{\prime}$-cyclic monophosphate formation by the cultured mesangial cells. Enhancement of adenylate cyclase activity by forskolin $\left(10^{-5} \mathrm{M}\right)$ also increased Ep production in the cell cultures. Our results suggest that hypoxia-stimulated Ep production by cultured mesangial cells is mediated by prostaglandins with subsequent stimulation of adenylate cyclase activity.

mesangial cells; hypoxia; adenylate cyclase; cyclic nucleotides

THERE IS EVIDENCE that hypoxia can induce release of prostaglandins in several organs $(3,15,16,25)$, including the kidney $(5,8,9,29)$. In addition, E-type prostaglandins appear to stimulate production of the glycoprotein hormone erythropoietin (Ep) both in vivo (30) and in the isolated perfused kidney (6). It therefore follows that prostaglandins could participate in the chain of events that link hypoxia with an increased Ep production.

We have recently shown that mesangial cells derived from rat renal glomeruli produce Ep activity in culture $(20,27)$. This Ep has free galactosyl residues at the carbohydrate moiety of the molecule and is therefore active only in vitro. The Ep activity was furthermore found to be inhibited by an antierythropoietin antibody. In addition, when the cells in culture were exposed to hypoxia or to cobaltous chloride, an increased production of Ep was observed. Based on these results the following questions have been addressed in the present study: I) do cultured mesangial cells increase production of prostaglandins on exposure to hypoxia?; 2) is cyclooxygenase activity necessary for stimulation of Ep production?; and 3) can prostaglandins enhance Ep production in mesangial cell cultures?

\section{METHODS}

Cell Cultures. Cultures of mesangial cells from rat renal glomeruli were established as described (18). In brief, glomeruli from male Sprague-Dawley rats weighing 100 $\mathrm{g}$ were isolated by a sieving technique and seeded in tissue culture flasks (Greiner, Nürtingen, FRG). The outgrowing cells were subcultured 21 days after the inoculation of the glomeruli. 'The identity of the cells was confirmed by immunofluorescence staining of desmin, a characteristic component of the cytoskeleton of renal mesangial cells both in vivo (2) and in vitro (20). The immunofluorescence procedure was performed exactly as described by Osborn and Weber (27). Affinity-purified antibody against desmin was generously provided by Dr. Mary Osborn (Göttingen).

The cells were cultured in medium RPMI 1640 (Boehringer, Mannheim) supplemented with $10 \%$ bovine serum (Boehringer, Mannhiem), $25 \mathrm{mM} \mathrm{N}$-2-hydroxyethylpiperazine- $N^{\prime}$-2-ethanesulfonic acid (HEPES), penicillin $(100 \mathrm{U} / \mathrm{ml})$, streptomycin $(100 \mu \mathrm{g} / \mathrm{ml})$, and bovine insulin $(0.66 \mathrm{U} / \mathrm{ml}$, Sigma Chemical). The tissue culture flasks were incubated in a humidified atmosphere in incubators controlled for $\mathrm{O}_{2}$ and $\mathrm{CO}_{2}$ (Heraeus; Hanau, FRG).

Prostaglandin assay. Prostaglandin $\mathrm{E}_{2}\left(\mathrm{PGE}_{2}\right)$ production was studied in medium from cultures containing $\sim 10^{6}$ mesangial cells per dish $\left(25 \mathrm{~cm}^{2}, 5 \mathrm{ml}\right.$ of culture medium) after $24 \mathrm{~h}$ of incubation at $5 \% \mathrm{CO}_{2}$ and either $20 \% \mathrm{O}_{2}$ (normoxia) or $2 \% \quad \mathrm{O}_{2}$ (hypoxia). The inferior surface of the cell culture dishes used in these experiments (Petriperm, Heraeus; Hanau, FRG) was gas permeable. $\mathrm{PGE}_{2}$ was assayed in the culture media by radioimmunoassay (New England Nuclear) without further extraction of culture media.

Determination of intracellular adenosine $3^{\prime}, 5^{\prime}$-cyclic monophosphate (cAMP) formation. Determination of cAMP production in intact cells in the presence of a phosphodiesterase inhibitor was carried out exactly as described in Ref. 1. In brief, confluent monolayers (7$\mathrm{cm}^{2}$ dishes) were washed with phosphate-buffered saline 
(PBS, pH 7.4) and incubated for $20 \mathrm{~min}$ at $37^{\circ} \mathrm{C}$ with PBS containing $0.2 \%$ bovine serum albumin and $1 \mathrm{mM}$ 3-isobutyl-1-methylxanthine (IBMX) with or without agent. Incubation was stopped by placing the dishes on ice. The culture medium was removed, and the cells were scraped with a Teflon policeman into $1 \mathrm{ml}$ of ice-cold buffer containing $5 \mathrm{mM}$ potassium phosphate, $2 \mathrm{mM}$ EDTA, 0.5 mM IBMX, and $150 \mathrm{mM} \mathrm{KCl} \mathrm{(pH} \mathrm{6.8).} \mathrm{The}$ suspension was sonicated, and an aliquot was removed for protein determination. The suspension was then boiled for $5 \mathrm{~min}$ and centrifuged at 7,000 $\mathrm{g}$ for $3 \mathrm{~min}$. Supernatants were assayed for cAMP by radioimmunoassay (New England Nuclear). Samples were diluted such that the final concentration of ED'TA in the assay tubes was $30-100 \mu \mathrm{M}$.

Effects of arachidonic acid (AA), prostaglandins $E_{2}, I_{2}$, and $F_{2(}$, indomethacin, and forskolin on Ep production. Stock solutions of AA, prostaglandins, and indomethacin were prepared in ethanol. The final concentration of ethanol in the medium was $<0.1 \%$. A stock solution of forskolin $\left(5 \times 10^{-2} \mathrm{M}\right)$ was prepared in dimethyl sulfoxide (DMSO). The final concentration of DMSO in the experiments was $<0.1 \%$. $\mathrm{PGE}_{2}, \mathrm{PGF}_{2 \kappa}$, and indomethacin were purchased from Sigma Chemical. $\mathrm{PGI}_{2}$ was kindly supplied by the Hoechst company (Darmstadt, FRG), and forskolin was a gift from Dr. H. Lang (Merck; Darmstadt, FRG).

Effects of the above agents on Ep production were assessed 3 days after addition to the culture media. Media from 10 identically treated $75-\mathrm{cm}^{2}$ flasks were pooled for each Ep determination.

Ep assay. Ep activity of the culture medium was determined by means of the fetal mouse liver cell (FMLC) test. In brief, a serum-free incubation mixture (10), as described previously (19), was employed. Standard Ep (human urinary Ep standardized against the International Reference Preparation B) was kindly provided by the National Institutes of Health (Bethesda, MD). All unknown samples from the culture supernatants were chromatographed on DEAE-cellulose at $\mathrm{pH} 4.5$. Only material that bound to DEAE-cellulose was used in the test. This was done to remove insulin, which stimulates the growth of late erythroid precursor cells independently of Ep (19). Samples so treated did not contain insulin on radioimmunoassay. Samples were then concentrated 10fold on Amicon YM-10 membranes before use. Pilot experiments showed that $70 \%$ of added erythropoietin was present after these incubation, purification, and concentration steps.

We chose the FMLC test for Ep assay because the mesangial cell-derived Ep molecule originally appeared to be inactive in the polycythemic mouse, a probable consequence of a modification in the carbohydrate moiety (20). Recently the study of Megaw and Johnson (23) came to our attention, showing that HEPES buffer alters the glycosylation of glycoproteins in cell cultures. Because we had regularly used HEPES buffer for the culture medium of mesangial cells, we assayed HEPESfree medium for mesangial cell cultures in the polycythemic mouse assay for Ep (13). The results (Table 1) clearly indicate that mesangial cells can produce an Ep molecule that is active in vivo in the absence of HEPES.
TABLE 1. Effects of medium on ${ }^{59} \mathrm{Fe}$-incorporation in red blood cells of exhypoxic polycythemic mice

\begin{tabular}{lc}
\hline & $\begin{array}{c}\% 59 \text { Fe-Incorpo- } \\
\text { ration in Red } \\
\text { Blood Cells }\end{array}$ \\
\hline $\begin{array}{l}\text { Mesangial cell-conditioned medium } \\
(30 \text {-fold concentrated) }\end{array}$ \\
$20 \% \mathrm{O}_{2}$ & \\
$5 \% \mathrm{O}_{2}$ & $1.47 \pm 0.39$ \\
$2 \% \mathrm{O}_{2}$ & $2.24 \pm 0.63 \dagger$ \\
Control medium (30-fold concentrated) & $4.23 \pm 0.80 \dagger$ \\
Standard erythropoietin & $1.02 \pm 0.12$ \\
$0 \mathrm{mU} / \mathrm{ml}$ & \\
$50 \mathrm{mU} / \mathrm{ml}$ & $0.83 \pm 0.21$ \\
$100 \mathrm{mU} / \mathrm{ml}$ & $2.18 \pm 0.41 \dagger$ \\
\hline
\end{tabular}

Values are means $\pm \mathrm{SE}$ of 4-7 separate samples. Assay used is described in Ref. 12 . ${ }^{*}$ RPMI 1640 supplemented with $10 \%$ fetal bovine serum and antibiotics. † Significantly different from $0 \mathrm{mU} /$ $\mathrm{ml}$ erythropoietin at $5 \%$ level.

TABLE 2. $P G E_{2}$ production in normoxic and hypoxic mesangial cell cultures

\begin{tabular}{|c|c|c|c|c|c|}
\hline \multirow[b]{2}{*}{$\begin{array}{l}\text { No. of } \\
\text { Passage }\end{array}$} & \multirow[b]{2}{*}{$\begin{array}{l}\text { No. of In- } \\
\text { dependent } \\
\text { Cell Lines }\end{array}$} & \multirow[b]{2}{*}{$\begin{array}{l}\text { Total No. } \\
\text { of Dishes } \\
\text { Studied }\end{array}$} & \multirow[b]{2}{*}{$\% \mathrm{O}_{2}$} & \multicolumn{2}{|c|}{$\mathrm{PGE}_{2}$ Production } \\
\hline & & & & $\begin{array}{c}\text { Range of cell } \\
\text { line means, ng. } \\
10^{6} \mathrm{cells}^{-1} \cdot 24 \\
\mathrm{~h}^{-1}\end{array}$ & $\begin{array}{l}\text { \%Change in in- } \\
\text { dividual dishes } \\
\text { in relation to re- } \\
\text { spective cell line } \\
\text { at } 20 \% \mathrm{O}_{2}{ }^{*}\end{array}$ \\
\hline $1 \mathrm{st}$ & 6 & $\begin{array}{l}21 \\
21\end{array}$ & $\begin{array}{r}20 \\
2\end{array}$ & $3.2-11.2$ & $\begin{array}{l}100 \pm 5 \\
151 \pm 14^{\dagger}\end{array}$ \\
\hline 2 nd & 4 & $\begin{array}{l}12 \\
12\end{array}$ & $\begin{array}{r}20 \\
2\end{array}$ & $2.5-22.5$ & $\begin{array}{l}100 \pm 6 \\
171 \pm 8\end{array}$ \\
\hline $3 \mathrm{rd}$ & 2 & $\begin{array}{l}8 \\
7\end{array}$ & $\begin{array}{r}20 \\
2\end{array}$ & $8.0-8.6$ & $\begin{array}{l}100 \pm 10^{\dagger} \\
180 \pm 13^{\dagger}\end{array}$ \\
\hline
\end{tabular}

To facilitate comparison between normoxia and hypoxia, mean values for each cell line during normoxia were normalized to $100 \%$; values for individual dishes of that line were expressed accordingly. Differences between grand means for hypoxia and normoxia were then tested by unpaired $t$ test for 1 st, $2 \mathrm{nd}$, and $3 \mathrm{rd}$ passage cultures. *Values are means \pm SE. $\quad+$ Significantly different from value at $20 \% \mathrm{O}_{2}(P<0.05$, Student's $t$ test $)$.

\section{RESULTS}

Table 2 summarizes effects of lowering the $\mathrm{O}_{2}$ concentration in the incubator on production of $\mathrm{PGE}_{2}$ by cultured mesangial cells. The data are based on findings from seven distinct cell lines. For each cell line, the mean $\mathrm{PGE}_{2}$ production rate was calculated from measurements in 2-6 individual dishes maintained at 20 or $2 \% \mathrm{O}_{2}$ for 3 days. There was considerable variation in the mean basal $\mathrm{PGE}_{2}$ production at $20 \% \mathrm{O}_{2}$ among the different cell lines (range $2.5-22.5 \mathrm{ng} \cdot 10^{6}$ cells $^{-1} \cdot 24 \mathrm{~h}^{-1}$ ). A similarly large scatter in $\mathrm{PGE}_{2}$ production was seen in the hypoxic cell cultures (range 4.8 $42.2 \mathrm{ng} \cdot 10^{6} \mathrm{cells}^{-1} \cdot 24 \mathrm{~h}^{-1}$ ), although in almost every case $\mathrm{PGE}_{2}$ production by the same cell line increased with hypoxia. Because of the cell line differences in $\mathrm{PGE}_{2}$ production, the $\mathrm{PGE}_{2}$ production rate of each individual dish was expressed as a percentage of the mean production rate seen with this specific cell line at $20 \% \mathrm{O}_{2}$. Hypoxic incubation $\left(2 \% \mathrm{O}_{2}\right)$ produced a significant increase in $\mathrm{PGE}_{2}$ production when compared with normoxic incubation $\left(20 \% \mathrm{O}_{2}\right)(P<0.05$, Table 2).

Figure 1 shows the effect of indomethacin on the 


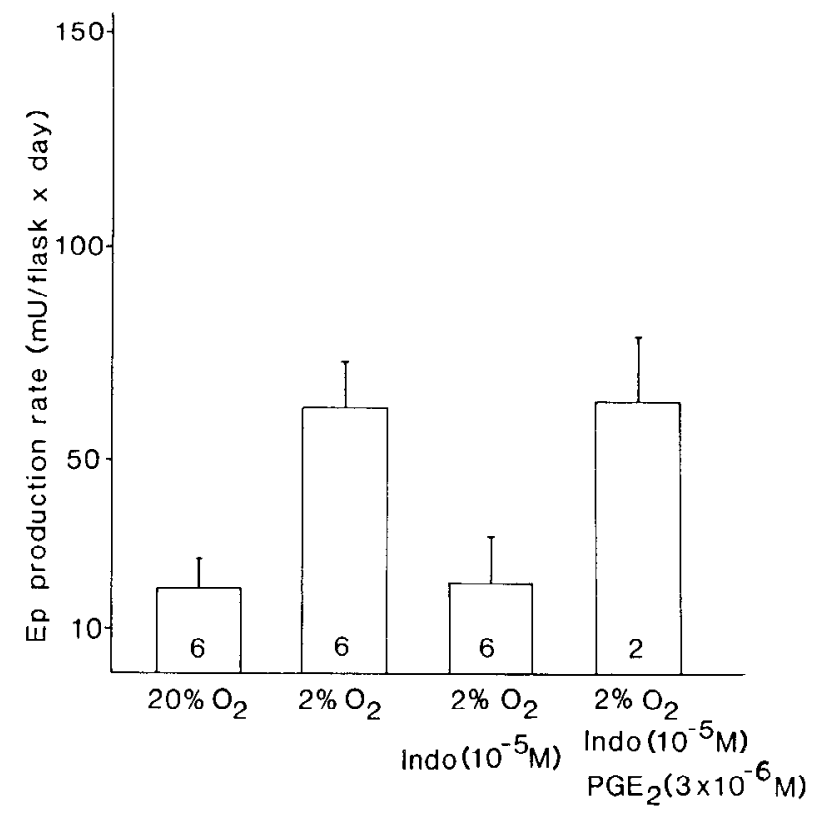

FIG. 1. Effects of indomethacin (Indo), alone and with prostaglandin $\mathrm{E}_{2}\left(\mathrm{PGE}_{2}\right)$, on erythropoietin $(\mathrm{Ep})$ production rate of cultured mesangial cells at $2 \% \mathrm{O}_{2}$. Data are presented as means \pm SE. Figures at bottom of columns indicate no. of independent experiments.

hypoxia-induced stimulation of Ep formation in cultured mesangial cells. Low $\mathrm{O}_{2}$ concentration in the incubation atmosphere ( $2 \%$ vs. $20 \%$ ) significantly enhanced Ep formation, in agreement with our earlier observations (20). Addition of $10^{-5} \mathrm{M}$ indomethacin completely abolished this stimulation of Ep formation. In view of the fact that indomethacin affects numerous cellular reactions apart from its main action as an inhibitor of cyclooxygenase (cf. Ref. 5), it was important to demonstrate that the observed effect on hypoxia-induced Ep production was not due to side effects of the drug. This was done by adding indomethacin and $\mathrm{PGE}_{2}$ simultaneously to cells kept in $2 \% \mathrm{O}_{2}$. As can be seen from Fig. 1, addition of $\mathrm{PGE}_{2}\left(3 \times 10^{-6} \mathrm{M}\right)$ completely restored the production of Ep in the presence of indomethacin. This result supports the contention that inhibition of hypoxia-induced Ep formation by indomethacin was due to inhibition of cyclooxygenase and not to other effects of the drug.

Addition to the culture medium of AA $\left(10^{-5} \mathrm{M}\right), \mathrm{PGE}_{2}$ $\left(10^{-6} \mathrm{M}\right)$, and $\mathrm{PGI}_{2}\left(10^{-4} \mathrm{M}\right)$ significantly raised $\mathrm{Ep}$ formation at normal $\mathrm{O}_{2}$ concentrations, while $\mathrm{PGF}_{2 \alpha}$ was without any effect (Fig. 2). Because $\mathrm{PGE}_{2}$ is the most abundant cyclooxygenase product of cultured mesangial cells from rats (29), we examined the interrelation between the concentration of added $\mathrm{PGE}_{2}$ and the formation of Ep. The results of this dose-response study are depicted in Fig. 3. It can be seen that the effect of $\mathrm{PGE}_{2}$ on formation of $\mathrm{Ep}$ was dependent on the $\mathrm{PGE}_{2}$ concentration and increased up to a concentration of $10^{-6} \mathrm{M}$. Because pilot studies had shown that at least $50 \%$ of added $\mathrm{PGE}_{2}$ (over the initial concentration range of $10^{-8}$ to $10^{-6} \mathrm{M}$ ) was present after the 3-day incubation period, it was important to exclude the porsibility that $\mathrm{PGE}_{2}$ carried over into the fetal liver cultures was confounding the Ep measurements. Consequently, we measured the effect of cultured media to which Ep or Ep plus $\mathrm{PGE}_{2}$

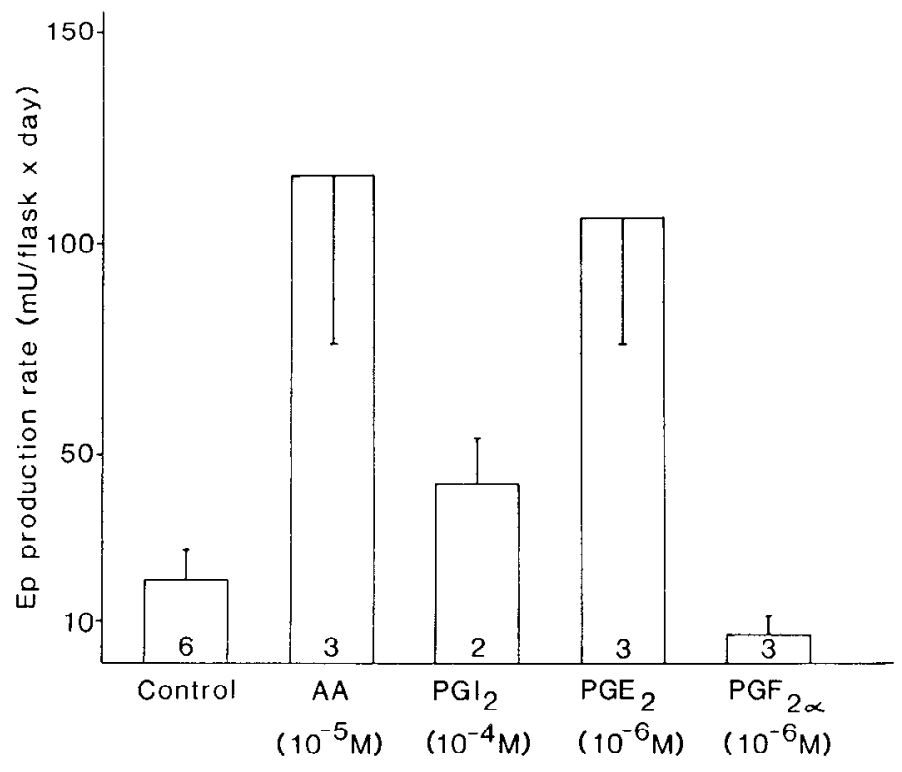

FIG. 2. Effects of added arachidonic acid (AA), prostaglandin $I_{2}$ $\left(\mathrm{PGI}_{2}\right), \mathrm{PGE}_{2}$, and $\mathrm{PGF}_{2 \alpha}$ on erythropoietin $(\mathrm{Ep})$ production rate of cultured mesangial cells at $20 \% \mathrm{O}_{2}$. Values and data are presented as described in legend to Fig. 1.

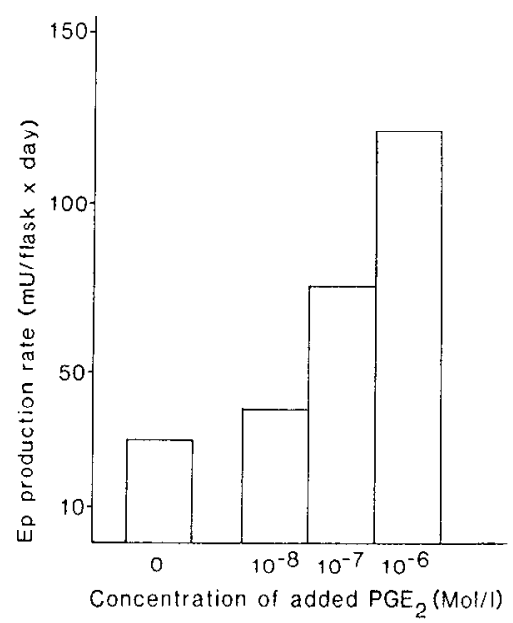

FIG. 3. Effects of different concentrations of added prostaglandin $\mathrm{E}_{2}\left(\mathrm{PGE}_{2}\right)$ on erythropoietin (Ep) production rate of cultured mesangial cells at $20 \% \mathrm{O}_{2}$. Experiments were performed simultaneously using 1 culture line. Data are presented as described in legend to Fig. 1.

$\left(10^{-6} \mathrm{M}\right)$ was added. We found (data not shown) that the recovery of Ep activity was independent of added $\mathrm{PGE}_{2}$, indicating that the carry-over of $\mathrm{PG}$ was negligible.

Because activation of adenylate cyclase by prostaglandins is a well-known phenomenon (32), we addressed the possibility that prostaglandins might stimulate Ep production in mesangial cells via this mechanism. We therefore studied the formation of intracellular cAMP in the presence of $\mathrm{AA}, \mathrm{PGI}_{2}$, and $\mathrm{PGE}_{2}$. Figure 4 shows that $\mathrm{AA}$ as well as prostacyclin increased the activity of the adenylate cyclase.

Figure 5 shows the dose-response relationship between intracellular cAMP formation and the $\mathrm{PGE}_{2}$ concentration in the culture medium. It is obvious that a $\mathrm{PGE}_{2}$ concentration of $3 \times 10^{-6} \mathrm{M}$ is sufficient to stimulate cAMP production maximally. In this dose-response study we also determined the amount of cAMP released 


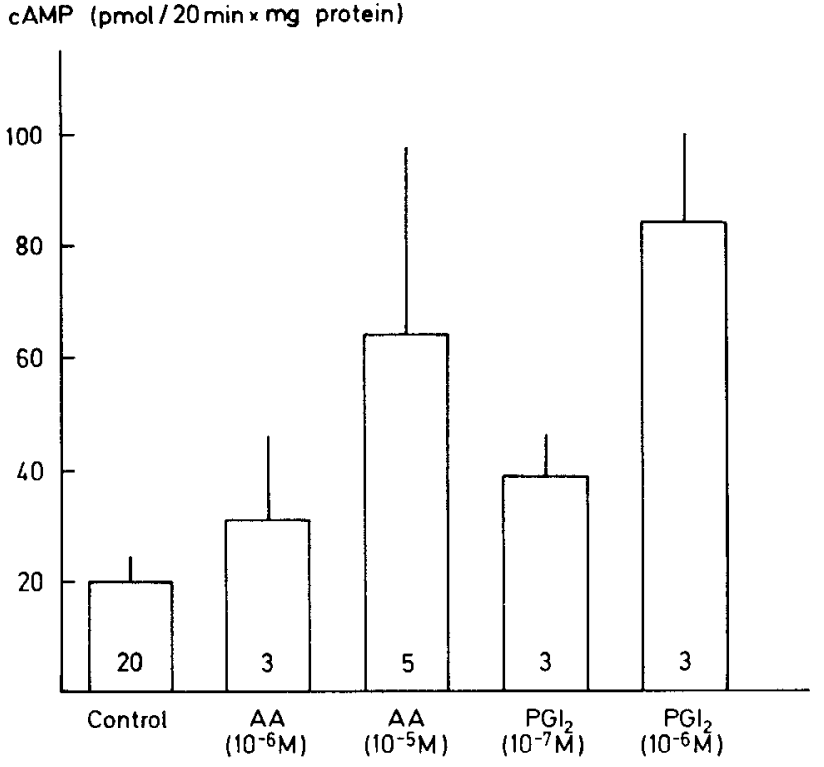

FIG. 4. Intracellular adenosine $3^{\prime}, 5^{\prime}$-cyclic monophosphate (cAMP) formation in cultured mesangial cells with and without added arachidonic acid (AA) or protaglandin $\mathrm{I}_{2}\left(\mathrm{PGI}_{2}\right)$. cAMP formation is given as pmol cAMP formed per $20 \mathrm{~min}$ per mg cellular protein. Data represent means \pm SE. Figures at bottom of columns indicate no. of experiments.

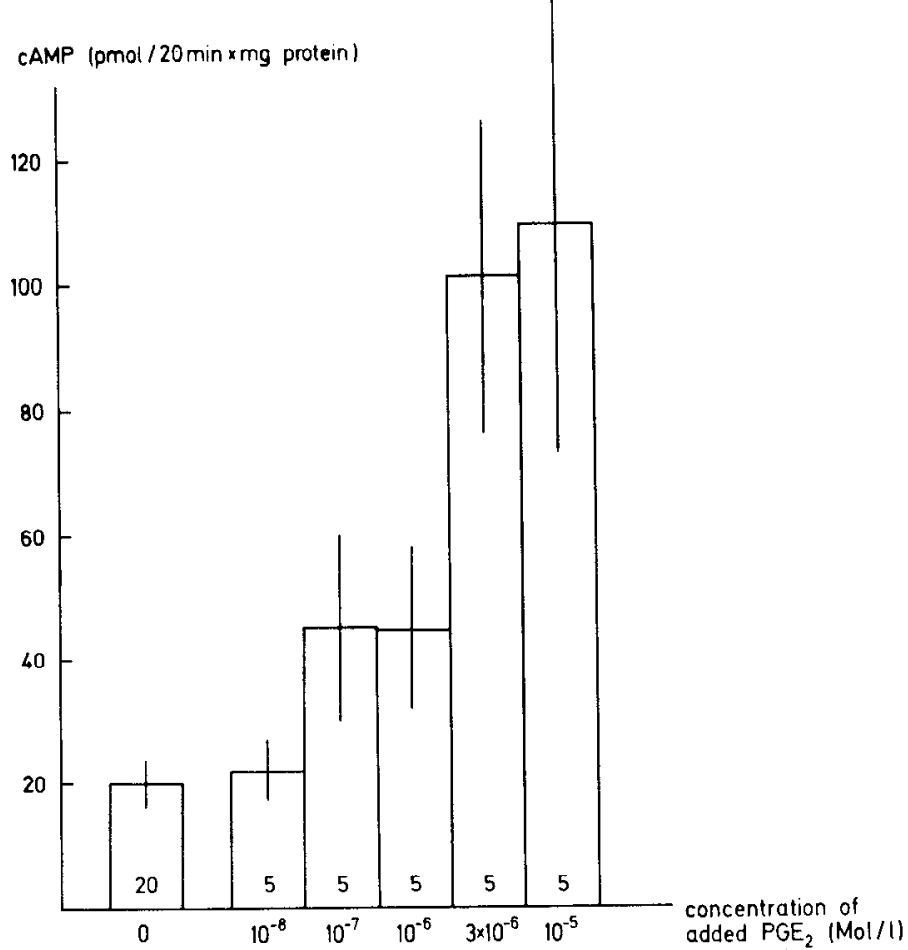

FIG. 5. Intracellular adenosine $3^{\prime}, 5^{\prime}$-cyclic monophosphate (cAMP) formation in cultured mesangial cells with different concentrations of added prostaglandin $\mathrm{E}_{2}\left(\mathrm{PGE}_{2}\right)$. Values and data are presented as described in legend to Fig. 4.

into the culture medium. We found a significant release of cAMP into the culture medium $(18 \pm 4.5 \mathrm{pmol}$ cAMP. $20 \mathrm{~min}^{-1} \cdot \mathrm{mg}$ protein; $n=4$ ). The release of cAMP, however, was independent of the $\mathrm{PGE}_{2}$ concentration added.

If the prostaglandin action on Ep synthesis in mesangial cells is mediated by an activation of adenylate cy-
TABLE 3. Erythropoietin production and intracellular cAMP formation by cultured mesangial cells in presence and absence of forskolin

\begin{tabular}{lcc}
\hline \hline & $\begin{array}{c}\text { Ep Production Rate, } \\
\mathrm{mU} \cdot \text { flask }^{-1} \cdot \text { day }^{-1}\end{array}$ & $\begin{array}{c}\text { cAMP Formation, } \\
\mathrm{pmol} \cdot \mathrm{mg}_{\text {motein }}^{-1} . \\
\mathrm{min}^{-1}\end{array}$ \\
\hline Control & $16 \pm 5$ & $20 \pm 4$ \\
& $(n=4)$ & $(n=4)$ \\
Forskolin, $10^{-5} \mathrm{M}$ & $45 \pm 6$ & $789 \pm 128$ \\
& $(n=3)$ & $(n=4)$ \\
\hline
\end{tabular}

Values are means \pm SE. Ep, erythropoietin; cAMP, adenosine $3^{\prime}, 5^{\prime}-$ cyclic monophosphate.

clase, then a prostaglandin-independent stimulation of adenylate cyclase should also increase Ep synthesis. We therefore tested the effect of the adenylate cyclase activator forskolin $\left(10^{-5} \mathrm{M}\right)$. Table 3 shows that forskolin significantly enhanced Ep production by a factor of about three. As expected, forskolin also strongly increased cAMP production.

\section{DISCUSSION}

In the present study we have presented several pieces of evidence that suggest that prostaglandins are involved in the hypoxia-induced production of Ep by cultured renal mesangial cells.

First, we have shown that exposure of mesangial cells in culture to low $\mathrm{O}_{2}$ concentrations enhances their formation of $\mathrm{PGE}_{2}$ (Table 2). An increase in $\mathrm{PGE}_{2}$ synthesis has also been observed in the intact kidney, both in renal ischemia (7) and hypoxic hypoxia (33). However, from these in vivo studies it is not possible to identify the type or types of cells that are responsible for the rise in $\mathrm{PGE}_{2}$ production. When the fractional contribution of mesangial cells to the whole kidney mass $(\sim 0.001)$ is considered in relation to the hypoxia-induced rise in $\mathrm{PGE}_{2}$ (about threefold) $(7,33)$, it seems probable that cells other than mesangial cells must account for the increase in $\mathrm{PGE}_{2}$ titers. It is thus difficult to relate hypoxia-induced prostaglandin formation and Ep production in studies performed with the intact kidney. The mechanism by which the synthesis of prostaglandins is enhanced in hypoxia is unknown. Conceivably, an initial step could be activation of phospholipase $\mathrm{C}$ by $\mathrm{ADP}$, which is known to increase under hypoxic conditions (34). At least in platelets, ADP leads to degradation of phosphatidylinositol and phosphatidylinositol 4,5-bisphosphate by phospholipase C, with sequential formation of 1,2-diacylglycerol and its phosphorylated product, phosphatidic acid (22). Intracellular accumulation of phosphatidic acid and lysophosphatidic acid, the product of degradation of phosphatidic acid by a specific phospholipase, $\mathrm{A}_{2}$, could then activate phospholipase $\mathrm{A}_{2}$, leading to the liberation of arachidonic acid, the rate-limiting substrate for prostaglandin synthesis (21). Experiments are in progress in this laboratory to evaluate the mechanisms by which hypoxia enhances prostaglandin formation.

A second piece of evidence implicating prostaglandin metabolism in Ep production during hypoxia is the inhibition of Ep production by indomethacin (Fig. 1). A 
similar decrease in Ep production has been documented in vivo with ischemic (7), hypoxic (24), and anemic (14) hypoxia in the presence of indomethacin. It should be emphasized here that the effect of indomethacin on Ep production reported in the present study was in all probability due to inhibition of cyclooxygenase and not to other biochemical actions of the drug (5). This can be inferred from the fact that added $\mathrm{PGE}_{2}$ completely restored Ep formation in cultured mesangial cells in the presence of indomethacin (Fig. 1). This conclusion is also supported by the observation that the stimulatory effect of cobaltous chloride on Ep formation in intact animals is not suppressed by doses of indomethacin that significantly reduce the effect of hypoxia on Ep production (14).

A third line of evidence suggesting prostaglandin involvement in the mediation of the Ep response to hypoxia is that arachidonic acid, as well as $\mathrm{PGE}_{2}$ and to a lesser extent $\mathrm{PGI}_{2}$, was found to enhance Ep production in the cultured mesangial cells, while $\mathrm{PGF}_{2 \alpha}$ was ineffective. A similar effect of $\mathrm{PGE}_{2}$ and some of its methylated analogues on radioiron incorporation in red cells of polycythemic mice has been identified (26), whereas $\mathrm{PGF}_{2 \alpha}$ was inactive at all concentrations tested (6). The increase in Ep levels observed in these studies could theoretically be due to release of stored Ep or to accelerated synthesis. We believe the latter possibility is far more likely. Thus in vivo studies by Schooley and Mahlmann (31) and Jelkmann and Bauer (12) clearly demonstrate the lack of significant Ep storage in the normoxic kidney. In view of that finding we conclude that Ep was produced rather than released by the cultured mesangial cells.

\section{REFERENCES}

1. Ausiello, D. A., J. I. Kreisberg, C. Roy, and M. J. Karnovsky. Contraction of cultured rat glomerular cells of apparent mesangial origin after stimulation with angiotensin II and arginine vasopressin. J. Clin. Invest. 65: 756-760, 1980.

2. Bachmann, S., W. Kriz, S. Kuhn, and W. W. Franke. Differentiation of cell types in the mammalian kidney by immunofluorescence microscopy using antibodies to intermediate filament proteins and desmoplakins. Histochemistry 77: 365-394, 1983.

3. Block, A. J., H. Feinberg, K. Herbaczynska-Cedro, and J. R. VANE. Anoxia-induced release of prostaglandins in rabbit isolated hearts. Circ. Res. 36: 34-41, 1975.

4. Dolby, T. W., A. Belmont, T. W. Barun, and C. Nicolini. DNA replication, chromatin structure, and histone phosphorylation altered by theophylline in synchronized HeLa S 3 cells. J. Cell Biol. 89: 78-85, 1981.

5. Dunn, M. W., AND E. J. Zambraski. Renal effects of drugs that inhibit prostaglandin synthesis. Kidney Int. 18: 609-622, 1980.

6. Gross, D. M., J. Brookins, G. D. Fink, and J. W. Fisher. Effects of prostaglandins $\mathrm{A}_{2}, \mathrm{E}_{2}$ and $\mathrm{F}_{2} \mathrm{q}$ on erythropoietin production. J. Pharmacol. Exp. Ther. 198: 489-496, 1976.

7. Gross, D. M., V. M. Mujovic, W. Jubiz, and J. W. Fisher. Enhanced erythropoietin and prostaglandin $\mathrm{E}$ production in the dog following renal artery constriction. Proc. Soc. Exp. Biol. Med. 151: 498-501, 1976.

8. Harkison, J. J., G. Schwoch, J. S. Schweppe, and R. A. JuNGMANN. Phosphorylative modification of histone $\mathrm{H}_{1}$ subspecies following isoproterenol and $\mathrm{N}^{6}, \mathrm{O}_{2}{ }^{\prime}$-dibutyryl-cyclic AMP stimulation of rat $\mathrm{C}_{6}$ glioma cells. J. Biol. Chem. 257: 13602-13609, 1982.

9. Herbaczynska-Decro, K., and J. F. VANe. Contribution of intrarenal generation of prostaglandins, autoregulation of renal blood (flow) in the dog. Circ. Res. 33: 428-436, 1973.

10. Iscove, N. N., L. J. Guilbert, and C. Weyman. Complete re-
The mechanism by which prostaglandins stimulate Ep production is unclear at this time. We found that AA, $\mathrm{PGI}_{2}$, and $\mathrm{PGE}_{2}$ evoked increased cAMP production in mesangial cells. Significantly, the prostaglandin-independent stimulation of adenylate cyclase by forskolin, a compound that acts directly on the catalytic subunit of the adenylate cyclase (32), also enhanced Ep production. These results suggest that prostaglandins increase Ep synthesis in mesangial cells by increasing intracellular cAMP levels via the activation of the adenylate cyclase. A positive correlation between cellular cAMP levels and Ep synthesis was postulated by Rodgers et al. in 1975 (28).

The mechanism by which cAMP might stimulate Ep synthesis is also unclear. cAMP-dependent protein kinases are known to phosphorylate a broad set of substrate proteins, including histone $\mathrm{H}_{1}(4,8)$. It is of interest that the phosphorylation of a very small percentage of the total histone pool may be sufficient to activate specific gene transcription (8). It is thus possible that $\mathrm{PGE}_{2}$ could act via cAMP-dependent protein kinases on those proteins that control the activity of the gene coding for Ep synthesis.

The skillful technical assistance of $\mathrm{R}$. Ludwig and L. Rauch is gratefully acknowledged. We furthermore are indebted to L. Schneider for her secretarial assistance. We are indebted to Dr. R. Woodson for his substantial help and criticism in the preparation of the manuscript.

This work was supported by the Sonderforschungsbereich 43 of the Deutsche Forschungsgemeinschaft.

Part of this work was presented at the 58th meeting of the German Physiological Society (17).

Received 2 August 1984; accepted in final form 10 January 1985.

placement of serum in primary cultures of erythropoietin-dependent red cell precursors (CFU-e) by albumin, transferrin, iron, unsaturated fatty acids, lecithin and cholesterol. Exp. Cell Res. 126: $121-126,1980$.

11. Jaffe, B. M., C. W. Parker, G. R. Marshall, and P. NeedleMAN. Renal concentration of prostaglandin $\mathrm{E}$ in acute and chronic renal ischemia. Biochem. Biophys. Res. Commun. 49: 754-765, 1972.

12. Jelkmann, W., AND C. Bauer. Demonstration of high levels of erythropoietin in rat kidneys following hypoxic hypoxia. Pfluegers Arch. 392: 34-39, 1981.

13. Jelkmann, W., A. Kurtz, and C. Bauer. In vitro production of erythropoietin. In: Kidney Hormones, edited by J. W. Fisher. New York: Academic, vol. 3. In press.

14. Jelkmann, W., A. Kurtz, J. Seidl, and C. Bauer. Mechanisms of renal glomerular erythropoietin production. Erwin-Riesch Symposium Proceedings, Westerland, edited by Grote and Witzlab. Wiesbaden, FRG: Springer Verlag, 1984, p. 130-137.

15. KaLSNER, S. The effect of hypoxia on prostaglandin output and on tone in isolated coronary arteries. Can. J. Physiol. Pharmacol. 55: 882-887, 1977.

16. Kirstein, A. Cardiac prostacyclin release: stimulation by hypoxia and various agents. Scand. J. Haematol. Suppl. 34: 105-110, 1979.

17. Kurtz, A., AND C. Bauer. Prostaglandin $\mathrm{E}_{2}$ is a signal molecule for hypoxia-induced erythropoietin production in renal mesangial cell cultures (Abstract). Naunyn-Schmiedebergs Arch. Pharmacol. Suppl. 322: R-23, 1983.

18. Kurtz, A., W. Jelkmann, and C. Bauer. Mesangial cells derived from rat glomeruli produce an erythropoiesis-stimulating factor in cell culture. FEBS Lett. 137: 129-132, 1982.

19. Kurtz, A., W. JelkmanN, and C. Bauer. Insulin stimulates erythroid colony formation independently of erythropoietin. $B r . J$. Haematol. 53: 311-316, 1983. 
20. Kurtz, A., W. Jelkmann, F. Sinowatz, and C. Bauer. Renal mesangial cells in culture in a model for study of erythropoietin production. Proc. Natl. Acad. Sci. USA 80: 4008-4011, 1983.

21. Lapetina, E. G., M. M. Billah, and P. Cuatrfcasas. The phosphatidylinositol cycle and the regulation of arachidonic acid production. Nature London 292: 367-369, 1981.

22. Lapetina, E. G., AND W. Siess. The role of phospholipase C in platelet responses. Life Sci. 33: 1011-1018, 1983.

23. Megaw, J. M., AND L. D. Johnson. Glycoprotein synthesis by cultured cells. Effect of serum concentration and buffers on sugar content. Proc. Soc. Exp. Biol. Med. 161: 60-65, 1979.

24. Mujovic, V. M., AND J. W. Fisher. The role of prostaglandins in the production of erythropoietin (ESF) by the kidney. II. Effects of indomethacin on erythropoietin production following hypoxia in dogs. Life Sci. 16: 463-473, 1975.

25. Needleman, P., M. S. Minkes, and J. R. Douglas. Stimulation of prostaglandin biosynthesis by adenine nucleotides. Circ. Res. 34: $455-460,1974$.

26. Nelson, P. K., J. BRookins, AND J. W. Fisher. Erythropoietic effects of prostacyclin $\left(\mathrm{PGI}_{2}\right)$ and its metabolite 6-keto-prostaglandin $\left(\mathrm{PGE}_{2}\right)$. J. Pharmacol. Exp. Ther. 226: 493-499, 1983.

27. OSBORN, M., AND K. WEBER. Immunofluorescence and immuno- cytochemical procedures with affinity-purified antibodies: tubulincontaining structures. Methods Cell Biol. 24: 97-132, 1983.

28. Rodgers, G. M., J. W. Fisher, and W. J. George. The role of renal adenosine $3^{\prime}, 5^{\prime}$-monophosphate in the control of erythropoietin production. Am. J. Med. 58: 31-38, 1975.

29. ScharschmidT, L. A., AND M. J. DUNN. Prostaglandin synthesis by rat glomerular cells in culture. J. Clin. Invest. 71: 1756-1764, 1983.

30. SCHOoley, J. C., AND L. J. Mahlmann. Stimulation of erythropoiesis in plethoric mice by prostaglandins and its inhibition by antierythropoietin. Proc. Soc. Exp. Biol. Med. 138: 523-524, 1971.

31. Schooley, J. C., AND L. J. Mahlmann. Fvidence for the de novo synthesis of erythropoietin in hypoxic rats. Blood 40:662-670, 1972.

32. Seamon, K. B., And J. W. Daly. Forskolin, cyclic AMP and cellular physiology. Trends Pharmacol. Sci. 4: 1-4, 1983.

33. WALKER, B. R. Diuretic response to acute hypoxia in the conscious dog. Am. J. Physiol. 243 (Renal Fluid Electrolyte Physiol. 12): F440F446, 1982 .

34. Wilson, D. F., M. Erecinska, C. Drown, and I. A. Silver. The oxygen dependence of cellular energy metabolism. Arch. Biochem. Biophys. 195: 485-493, 1979.

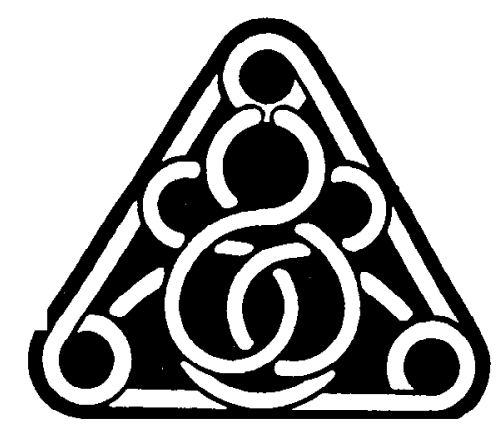

